\title{
Economic Evaluation of Farming Residues Recycling in Sharkia Governorate
}

\section{Prof./ Ali Ahmed Ibrahim Dr/ Hadil Taher Hasanien}

Dr/Ahmed El Sayed Mohammed

\section{Dept. of Agricultural Economics, Faculty of Agriculture, Zagazig University \\ Introduction}

$95 \%$ of egyptian area is desert and only $5 \%$ of the land area is actually occupied with less than $4 \%$ of the land is suitable for agriculture. The agricultural activates result in "the yield" which is economic part of the crop and less important part which used to be called "agricultural waste". Therefore, agricultural waste is defined as the outcome of agricultural production following the different harvesting activities.

Agricultural wastes in Egypt amount to about 30-35 million tons a year of which only 7 million tons as animal feed and 4 million as organic manure are being utilized. These crop residues results after harvesting in the farm of leaves, stem and shelves which are characterized as Coarse plant byproducts and big size, chemically low in protein and fat contents, also it is high in lignin and cellulous contents.

The main problems facing rural Production that agriculture wastes becomes very obvious and aggregated after the harvest of crops that is because farmer is in a rush to re-cultivate his land therefore getting rid of the wastes has his highest priorities, usually by burning. This method, burning not only is considered an economic loss but also has harmful effects on the environment, these harmful effects are emission of poisons gases to the air and reducing the microbial activities in the soil. In addition, storing these wastes in the field after compacting may make it suitable environment for reproduction and growth of pests and pathogens that will attack new crops.

\section{Main Objectives}

Processing and utilization of agriculture wastes in any other environmentally friendly way is very important, these can be done by: Compost production by fermenting the agricultural in the main way for recycling them, and animal fodder production by treating some wastes increase its nitrogen content hence its nutritional value. So it can be concluded that recycling agriculture wastes is a must for environment as well as economical saving. This recycling will not only increase agricultural production but also will improve its quality.

Analyzing and estimating the expected economic evaluation of crop residues recycling is the main objective of the study. This objective can be studied through the following objectives:

- Estimating the by-products values generated from the main crops (i.e., cotton, wheat, rice, maize, sugar beet) cultivated in Sharkia governorate.

- Measuring and estimating the technical and economic efficient indicators of the most important farming residues recycling in Sharkia governorate.

- Understanding the inputs-outputs of crop residues for conservation agriculture in Sharkia governorate.

- Estimating the economic evaluation of soil nutrients compounds (organic matter, nitrogen, phosphate, potassium and total digestible nutrients (TDN)) as result of the processing and recycling the studied farming residues in Sharkia Governorate. 
- Estimating the labour opportunities as result of the processing and recycling the studied farming residues in Sharkia Governorate.

\section{Methodology and data sources}

To accomplish the previous objectives, the descriptive and the statistical analysis has been applied. In addition the complete and partial crop budgets have been used to analyze the on farm incomes. The crop residues budgets have been computed for the main cultivated crops, i.e., sugar beet, rice, wheat, maize and cotton. These crops have been chosen based on the cultivation area in Sharkia governate during the period 2006-2011, table1. The main economic efficiency indicators for the main crops residues have been calculated using the residues budgets. These indicators are: (i) total costs per ton of compost or nontraditional fodder, (ii) net profit per ton of residues, compost, fodder and feddan, and (iii) the farmer margin and incentive per ton of compost or nontraditional fodder. This study is based on secondary data obtained from the Central Agency for Public Mobilization and Statistics, the Central Department of Agricultural Economics, Ministry of Agriculture, unpublished data.

\section{Results and discussion}

\section{1- The importance of raw residues for the cultivated crops.}

The average cultivated areas, yields, prices and values of by-products of the main cultivated crops in Sharkia governorate during the period 2006-2011 are presented in table (1). Data in the table indicate that: (i) area of wheat $(40.2 \%)$, rice $(28.9 \%)$, summer maize $(14.2 \%)$, tomato $(4.6 \%)$, cotton $(4.5 \%)$, sugar beet $(2.8 \%)$, faba bean $(2 \%)$ and peanuts $(2 \%)$ are the main cultivated crops in the governorate. (ii) the value of raw residues of the wheat, rice, summer maize, tomato, cotton, sugar beet, faba bean, peanuts and barley are estimated at 460 million LE, 56.5 million LE, 27.5 million LE, 2.7 million LE, 6.24 million LE, 17.8 million LE, 9.4 million LE, 2.4 million LE and 12.98 million LE, respectively.

Table 1: The averages cultivated areas, yields, prices and values of by-products of the main cultivated crops in Sharkia governorate during the period 2006-2011.

\begin{tabular}{|l|c|c|c|c|c|}
\hline \multirow{2}{*}{ Crop } & \multicolumn{2}{|c}{ Cultivated Area } & \multicolumn{3}{c|}{ By- products } \\
\cline { 2 - 6 } & Feddan & $\%$ & $\begin{array}{c}\text { quantity } \\
\text { (tons/feddan) }\end{array}$ & Price (LE/ton) & $\begin{array}{c}\text { value }(000 \\
000 \mathrm{LE})\end{array}$ \\
\hline Wheat & 380471.30 & $40.2 \%$ & 3.21 & 376.70 & 460.07 \\
\hline Rice & 273141.80 & $28.9 \%$ & 2.14 & 96.70 & 56.52 \\
\hline Summer Maize & 134116.50 & $14.2 \%$ & 2.15 & 95.30 & 27.48 \\
\hline Cotton & 42955.80 & $4.5 \%$ & 1.69 & 86.00 & 6.24 \\
\hline Sugar beet & 26794.30 & $2.8 \%$ & 4.36 & 152.50 & 17.82 \\
\hline Faba bean & 19343.00 & $2.0 \%$ & 1.89 & 256.00 & 9.36 \\
\hline Peanuts & 18521.20 & $2.0 \%$ & 1.26 & 102.70 & 2.40 \\
\hline Barley & 12400.00 & $1.3 \%$ & 3.14 & 333.30 & 12.98 \\
\hline Trefoil Rabaah & 11749.20 & $1.2 \%$ & 2.00 & 5120.00 & 120.31 \\
\hline Maaize Nile & 10469.70 & $1.1 \%$ & 1.98 & 99.30 & 2.06 \\
\hline Sesame & 7181.20 & $0.76 \%$ & 1.17 & 102.00 & 0.86 \\
\hline Onions & 3354.50 & $0.35 \%$ & & & 0.00 \\
\hline Flax & 2129.20 & $0.22 \%$ & 1.32 & 1738.50 & 4.89 \\
\hline Lupine & 1916.20 & $0.20 \%$ & 1.23 & 220.67 & 0.52 \\
\hline Garlic & 1320.30 & $0.14 \%$ & & & 0.00 \\
\hline Lentils & 605.70 & $0.06 \%$ & 1.04 & 236.00 & 0.15 \\
\hline Chickpea & 24.30 & $0.00 \%$ & 9.56 & 209.00 & 0.05 \\
\hline Fenugreek & 208.00 & $0.02 \%$ & 188.00 & 2.00 & 0.08 \\
\hline Tomato & 43133.30 & $4.6 \%$ & 2.50 & 25.00 & 2.70 \\
\hline Potato & 11291.70 & $1.2 \%$ & 2.00 & 25.00 & 0.56 \\
\hline Total & 946702.20 & $100.0 \%$ & & & 725.03 \\
\hline
\end{tabular}

source : The Central Department of Agricultural Economics, Ministry of Agriculture. 


\section{2- The main farm residues for conservation agriculture.}

- Farm residual processing:

Crop residues are organic and biodegradable mater. Utilization technology must either use the residues rapidly, or the residues must be stored under conditions that do not cause spoilage or render the residues unsuitable for processing to the desired end product so in this part of the study the processed wheat, faba been and rice nontraditional fodder budgets have been computed and studied. Also the processed cotton, maize, tomato and sugar beet compost budget has been calculated and studied. The economic profitability measures have been estimated for the nontraditional fodder and the compost.

\section{3- Expected Economic evaluation of Nontraditional Fodder Recycling.}

In this part of the study farming residues budgets for the nontraditional fodder recycling of the main cultivated crops are estimated. The main economic efficient indicators such as: (i) total costs per ton, per feddan and per governorate of nontraditional fodder, (ii) the net profit per ton of raw residues, per feddan, per governorate of fodder, (iii) the farmer incentive and margin per ton of fodder, and (iv) the items of the costs structure per feddan and per governorate of the fodder are estimated and discussed in details.

\section{1- Wheat}

The inputs and outputs data for the wheat nontraditional budget per feddan and per governorate are presented in table2. The main results shown in the table can be summarized as follows: (i) the average yields of wheat strew are estimated at 3.29 ton per feddan and 1.25 million ton per governorate, respectively. The price of nontraditional fodder is estimated at $1500 \mathrm{LE} /$ ton. Therefore the total return of wheat nontraditional fodder per feddan and per governorate is estimated at L.E 4935 and LE1.88 billion, respectively. (ii) The total costs of wheat nontraditional fodder per feddan and per governorate are estimated at L.E 1613.5 and LE,613.8 million respectively. The costs of wheat strew, plastic cover, urea, molas, machinery, labor and water is estimated at $75 \%, 5 \%, 2 \%, 6 \%, 8 \%, 3 \%$ and $0.0 \%$, respectively of the total costs. the depreciation as a fixed cost is estimated at $2 \%$ of the total costs. (iii) the net profits per feddan and per governorate are estimated at LE 3322 and L.E1.263 billion, respectively. (iv) the net profits per ton of raw residues and per ton of fodder are estimated at L.E 1035 and LE 1010, respectively. (v) the farmer margin and incentive per ton of fodder are estimated at LE 1010 and 67\%, respectively. (vi) the total costs per ton of fodder is estimated at $490 \mathrm{LE} / \mathrm{ton}$.

\section{2- Rice}

The inputs and outputs data for rice nontraditional budget per feddan and per governorate are presented in table (3). The main results shown in the table can be summarized as follows: (i) the average yields of the rice strew are estimated at 2.14 ton per feddan and 599 thousand ton per governorate, respectively. The price of nontraditional fodder is estimated at $400 \mathrm{LE} / \mathrm{ton}$. Therefore the total returns of rice nontraditional fodder per feddan and per governorate are estimated at $877 \mathrm{~L}$.E/feddan and 239.7 million LE/ governorate, respectively. (ii) The total costs of rice nontraditional fodder per feddan and per governorate are estimated at $476 \mathrm{~L}$.E/feddan and 130 million LE / governorate, respectively. The costs of rice strew, plastic cover, 
Table (2): the wheat nontraditional fodder budget for feddan and for governorate, 2006-2011

\begin{tabular}{|c|c|c|c|c|c|c|c|c|}
\hline \multirow[b]{2}{*}{ Item } & \multirow[b]{2}{*}{ Unit } & \multicolumn{3}{|c|}{ per feddan } & \multicolumn{3}{|c|}{ per governorate } & \multirow[b]{2}{*}{$\%$} \\
\hline & & $\begin{array}{l}\text { Quantity } \\
\text { (ton/fed) }\end{array}$ & $\begin{array}{c}\text { Price } \\
\text { (LE/unit) }\end{array}$ & $\begin{array}{l}\text { Value } \\
\text { (LE) }\end{array}$ & $\underset{\text { (ton) }}{\text { Quantity }}$ & $\begin{array}{c}\text { Price } \\
\text { (LE/unit) }\end{array}$ & Value (LE) & \\
\hline \multicolumn{9}{|l|}{ I. Output Items } \\
\hline - Main Product (fodder) & Ton & 3.290 & 1500.00 & 4935.38 & 1251846 & 1500.00 & 1877768542 & $100 \%$ \\
\hline Total Output & $\mathrm{LE}$ & & & 4935.38 & & & 1877768542 & \\
\hline \multicolumn{9}{|l|}{ II. Cost Items } \\
\hline \multicolumn{9}{|l|}{ Variable costs: } \\
\hline 1. wheat residuals & Ton & 3.21 & 376.70 & 1209.21 & 1221313 & 376.70 & 460068559 & $75 \%$ \\
\hline 2. Plastic cover & $\mathrm{m} 3$ & 19.26 & 4.00 & 77.04 & 7327877 & 4.00 & 29311509 & $5 \%$ \\
\hline 3. Chemicals: & & & & 0.00 & & & 0 & \\
\hline - Urea & $\mathrm{Kg}$ & 16.05 & 2.00 & 32.10 & 6106564 & 2.00 & 12213129 & $2 \%$ \\
\hline Molas & $\mathrm{Kg}$ & 80.25 & 1.25 & 100.31 & 30532822 & 1.25 & 38166027 & $6 \%$ \\
\hline 4. Machinery & HR & 2.57 & 50.00 & 128.40 & 977050 & 50.00 & 48852515 & $8 \%$ \\
\hline 5. Labor & Manday & 0.64 & 50.00 & 32.10 & 244263 & 50.00 & 12213129 & $2 \%$ \\
\hline 6. water & $\mathrm{m} 3$ & 0.16 & 0.50 & 0.08 & 61066 & 0.50 & 30533 & $0.00 \%$ \\
\hline sub-total & LE & & & 1579.24 & & & 600855401 & $98 \%$ \\
\hline \multicolumn{9}{|l|}{ Fixed costs: } \\
\hline Depreciation & $\mathrm{LE}$ & 218000 & $14 \%$ & 34.24 & 218000 & $14 \%$ & 13025744 & $2 \%$ \\
\hline sub-total & $\mathrm{LE}$ & & & 34.24 & & & 13025744 & $2 \%$ \\
\hline Total Cost & $\mathrm{LE}$ & & & 1613.48 & & & 613881145 & $100 \%$ \\
\hline \multicolumn{9}{|l|}{ III. Profit Account: } \\
\hline - Net Profit/fed. or gov. & LE/fed. & & & 3322 & & & 1263887398 & \\
\hline - Net Profit/ton of residues & LE/ton & & & 1035 & & & 1035 & \\
\hline - Net Profit/ton of fodder & LE/ton & & & 1010 & & & 1010 & \\
\hline - Revenue/ton & LE/ton & & & 1500 & & & 1500 & \\
\hline - Total cost/ton & LE/ton & & & 490 & & & 490 & \\
\hline - Farmer incentive & $\%$ & & & $67 \%$ & & & $67 \%$ & \\
\hline - Farmer margin & LE/ton & & & 1010 & & & 1010 & \\
\hline
\end{tabular}

source : Computed and applied from the Central Department of Agricultural Economics, Ministry of Agriculture. 
Table (3): the rice nontraditional fodder budget for feddan and for governorate, 2006-2011

\begin{tabular}{|c|c|c|c|c|c|c|c|c|}
\hline \multirow[b]{2}{*}{ Item } & \multirow[b]{2}{*}{ Unit } & \multicolumn{3}{|c|}{ per feddan } & \multicolumn{3}{|c|}{ per governorate } & \multirow[b]{2}{*}{$\%$} \\
\hline & & $\begin{array}{l}\text { Quantity } \\
\text { (ton/fed) }\end{array}$ & $\begin{array}{c}\text { Price } \\
\text { (LE/unit) }\end{array}$ & $\begin{array}{l}\text { Value } \\
\text { (LE) }\end{array}$ & $\begin{array}{c}\text { Quantity } \\
\text { (ton) }\end{array}$ & $\begin{array}{c}\text { Price } \\
\text { (LE/unit) }\end{array}$ & $\begin{array}{l}\text { Value } \\
\text { (LE) }\end{array}$ & \\
\hline \multicolumn{9}{|l|}{ I. Output Items } \\
\hline - Main Product (fodder) & ton & 2.194 & 400.00 & 877.40 & 599137 & 400.00 & 239654615 & $100 \%$ \\
\hline Total Output & LE & & & 877.40 & & & 239654615 & \\
\hline \multicolumn{9}{|l|}{ II. Cost Items } \\
\hline \multicolumn{9}{|l|}{ Variable costs: } \\
\hline 1. rice residuals & ton & 2.14 & 96.70 & 206.94 & 584523 & 96.70 & 56523418 & $43 \%$ \\
\hline 2. Plastic cover & $\mathrm{m} 3$ & 12.84 & 4.00 & 51.36 & 3507141 & 4.00 & 14028563 & $11 \%$ \\
\hline 3. Chemicals: & & & & 0.00 & & & 0 & $0 \%$ \\
\hline - Urea & $\mathrm{kg}$ & 10.70 & 2.00 & 21.40 & 2922617 & 2.00 & 5845235 & $4 \%$ \\
\hline Molas & $\mathrm{kg}$ & 53.50 & 1.25 & 66.88 & 14613086 & 1.25 & 18266358 & $14 \%$ \\
\hline 4. Machinery & $\mathrm{HR}$ & 1.71 & 50.00 & 85.60 & 467619 & 50.00 & 23380938 & $18 \%$ \\
\hline 5. Labor & manday & 0.43 & 50.00 & 21.40 & 116905 & 50.00 & 5845235 & $4 \%$ \\
\hline 6. water & $\mathrm{m} 3$ & 0.11 & 0.50 & 0.05 & 29226 & 0.50 & 14613 & $0 \%$ \\
\hline sub-total & LE & & & 453.63 & & & 123904359 & $95 \%$ \\
\hline Fixed costs: & & & & & & & & $0 \%$ \\
\hline Depreciation & LE & 218000 & $14 \%$ & 22.82 & 218000 & $14 \%$ & 6234154 & $5 \%$ \\
\hline sub-total & $\mathrm{LE}$ & & & 22.82 & & & 6234154 & $5 \%$ \\
\hline Total Cost & $\mathrm{LE}$ & & & 476.45 & & & 130138513 & $100 \%$ \\
\hline \multicolumn{9}{|l|}{ III. Profit Account: } \\
\hline - Net Profit/fed. or gov. & LE/fed. & & & 401 & & & 109516102 & \\
\hline - Net Profit/ton of residues & LE/ton & & & 187 & & & 187 & \\
\hline - Net Profit/ton of fodder & LE/ton & & & 183 & & & 183 & \\
\hline - Revenue/ton & LE/ton & & & 400 & & & 400 & \\
\hline - Total cost/ton & LE/ton & & & 217 & & & 217 & \\
\hline - Farmer incentive & $\%$ & & & $46 \%$ & & & $46 \%$ & \\
\hline - Farmer margin & LE/ton & & & 183 & & & 183 & \\
\hline
\end{tabular}

source : Computed and applied from the Central Department of Agricultural Economics, Ministry of Agriculture. 
urea, molas, machinery, labor and water is estimated at 43\%, 11\%, 4\%, 14\%, 18\%, $4 \%$ and $0.0 \%$, respectively of the total costs. the depreciation as a fixed cost is estimated at $5 \%$ of the total costs. (iii) the net profits per feddan and per governorate are estimated at $401 \mathrm{LE} /$ feddan and 109.5 million L.E/governorate, respectively. (iv) the net profits per ton of raw residues and per ton of fodder are estimated at L.E 187 and LE 183, respectively. (v) the farmer margin and incentive per ton of fodder are estimated at LE 183 and 46\%, respectively. (vi) the total costs per ton of fodder is estimated at $217 \mathrm{LE} /$ ton.

\section{3- Faba bean}

The inputs and outputs data for the faba bean nontraditional budget per feddan and per governorate are presented in table (4). The main finds shown in the table can be summarized as follows: (i) the average yields of the faba bean strew are estimated at 1.89 ton per feddan and 36.6 thousand ton per governorate, respectively. The price of nontraditional fodder is estimated at $1500 \mathrm{LE} / \mathrm{ton}$. Therefore the total returns of faba bean nontraditional fodder per feddan and per governorate are estimated at 2906 L.E/feddan and 56.2 million LE/ governorate, respectively. (ii) The total costs of faba bean nontraditional fodder per feddan and per governorate are estimated at 722 L.E/feddan and 13.9 million LE / governorate, respectively. The costs of faba bean strew, plastic cover, urea, molas, machinery, labor and water is estimated at $67 \%$, $6 \%, 3 \%, 8 \%, 10 \%, 3 \%$ and $0.0 \%$, respectively of the total costs. the depreciation as a fixed cost is estimated at $3 \%$ of the total costs. (iii) the net profits per feddan and per governorate are estimated at $2841 \mathrm{LE} /$ feddan and $42.2 \mathrm{million} \mathrm{L} . \mathrm{E} /$ governorate, respectively. (iv) the net profits per ton of raw residues and per ton of fodder are estimated at L.E 1156 and LE 1127, respectively. (v) the farmer margin and incentive per ton of fodder are estimated at LE 1127 and 75\%, respectively. (vi) the total costs per ton of fodder is estimated at $373 \mathrm{LE} / \mathrm{ton}$.

\section{4- Maize}

The inputs and outputs data for the maize nontraditional budget per feddan and per governorate are presented in table (5). The main finds shown in the table can be summarized as follows: (i) the average yields of the maize residues are estimated at 2.15 ton per feddan and 311 thousand ton per governorate, respectively. The price of nontraditional fodder is estimated at $500 \mathrm{LE} /$ ton. Therefore the total returns of maize nontraditional fodder per feddan and per governorate are estimated at 1102 L.E/feddan and 159.3 million LE/governorate, respectively. (ii) The total costs of maize nontraditional fodder per feddan and per governorate are estimated at 476 L.E/feddan and 68.8 million LE/governorate, respectively. The costs of maize residues, plastic cover, urea, molas, machinery, labor and water is estimated at $43 \%$, $11 \%, 5 \%, 14 \%, 18 \%, 5 \%$ and $0.0 \%$, respectively of the total costs. the depreciation as a fixed cost is estimated at $5 \%$ of the total costs. (iii) the net profits per feddan and per governorate are estimated at $626 \mathrm{LE} /$ feddan and 90.5 million L.E/governorate, respectively. (iv) the net profits per ton of raw residues and per ton of fodder are estimated at L.E 291 and LE 284, respectively. (v) the farmer margin and incentive per ton of fodder are estimated at LE 284 and 57\%, respectively. (vi) the total costs per ton of fodder is estimated at $216 \mathrm{LE} /$ ton. 
المجلة المصرية للاقتصاد الزراعي - الخامس والعشرون - العدد الأول - مارس 10 ب.

Table (4): the faba bean nontraditional fodder budget for feddan and for governorate, 2006-2011

\begin{tabular}{|c|c|c|c|c|c|c|c|c|}
\hline \multirow[b]{2}{*}{ Item } & \multirow[b]{2}{*}{ Unit } & \multicolumn{3}{|c|}{ per feddan } & \multicolumn{3}{|c|}{ per governorate } & \multirow[b]{2}{*}{$\%$} \\
\hline & & $\begin{array}{l}\text { Quantity } \\
\text { (ton/fed) }\end{array}$ & $\begin{array}{c}\text { Price } \\
\text { (LE/unit) }\end{array}$ & $\begin{array}{l}\text { Value } \\
\text { (LE) }\end{array}$ & $\begin{array}{c}\text { Quantity } \\
\text { (ton) }\end{array}$ & $\begin{array}{c}\text { Price } \\
\text { (LE/unit) }\end{array}$ & $\begin{array}{l}\text { Value } \\
\text { (LE) }\end{array}$ & \\
\hline \multicolumn{9}{|l|}{ I. Output Items } \\
\hline - Main Product (fodder) & Ton & 1.937 & 1500.00 & 2905.88 & 37472 & 1500.00 & 56208340 & $100 \%$ \\
\hline Total Output & $\mathrm{LE}$ & & & 2905.88 & & & 56208340 & \\
\hline \multicolumn{9}{|l|}{ II. Cost Items } \\
\hline \multicolumn{9}{|l|}{ Variable costs: } \\
\hline 1. faba bean residuals & Ton & 1.89 & 256.00 & 483.84 & 36558 & 256.00 & 9358917 & $67 \%$ \\
\hline 3. Chemicals: & & & & 0.00 & & & 0 & $0 \%$ \\
\hline - Urea & $\mathrm{Kg}$ & 9.45 & 2.00 & 18.90 & 182791 & 2.00 & 365583 & $3 \%$ \\
\hline Molas & $\mathrm{Kg}$ & 47.25 & 1.25 & 59.06 & 913957 & 1.25 & 1142446 & $8 \%$ \\
\hline 4. Machinery & $\mathrm{HR}$ & 1.51 & 50.00 & 75.60 & 29247 & 50.00 & 1462331 & $10 \%$ \\
\hline 5. Labor & Manday & 0.38 & 50.00 & 18.90 & 7312 & 50.00 & 365583 & $3 \%$ \\
\hline 6. water & $\mathrm{m} 3$ & 0.09 & 0.50 & 0.05 & 1828 & 0.50 & 914 & $0 \%$ \\
\hline sub-total & $\mathrm{LE}$ & & & 701.71 & & & 13573172 & $97 \%$ \\
\hline Fixed costs: & & & & & & & & $0 \%$ \\
\hline Depreciation & $\mathrm{LE}$ & 218000 & $14 \%$ & 20.16 & 218000 & $14 \%$ & 389907 & $3 \%$ \\
\hline Total Cost & $\mathrm{LE}$ & & & 721.87 & & & 13963079 & $100 \%$ \\
\hline \multicolumn{9}{|l|}{ III. Profit Account: } \\
\hline - Net Profit/fed. or gov. & LE/fed. & & & 2184 & & & 42245261 & \\
\hline $\begin{array}{l}\text { - Net Profit/ton of } \\
\text { residues }\end{array}$ & LE/ton & & & 1156 & & & 1156 & \\
\hline - Net Profit/ton of fodder & LE/ton & & & 1127 & & & 1127 & \\
\hline - Revenue/ton & LE/ton & & & 1500 & & & 1500 & \\
\hline - Total cost/ton & LE/ton & & & 373 & & & 373 & \\
\hline - Farmer incentive & $\%$ & & & $75 \%$ & & & $75 \%$ & \\
\hline - Farmer margin & LE/ton & & & 1127 & & & 1127 & \\
\hline
\end{tabular}

source : Computed and applied from the Central Department of Agricultural Economics, Ministry of Agriculture. 
Table (5): the maize nontraditional fodder budget for feddan and for governorate, 2006-2011

\begin{tabular}{|c|c|c|c|c|c|c|c|c|}
\hline \multirow[b]{2}{*}{ Item } & \multirow[b]{2}{*}{ Unit } & \multicolumn{3}{|c|}{ per feddan } & \multicolumn{3}{|c|}{ per governorate } & \multirow[b]{2}{*}{$\%$} \\
\hline & & $\begin{array}{l}\text { Quantity } \\
\text { (ton/fed) }\end{array}$ & $\begin{array}{c}\text { Price } \\
\text { (LE/unit) }\end{array}$ & $\begin{array}{l}\text { Value } \\
\text { (LE) }\end{array}$ & $\underset{\text { (ton) }}{\text { Quantity }}$ & $\begin{array}{l}\text { Price } \\
\text { (LE/unit) }\end{array}$ & $\begin{array}{l}\text { Value } \\
\text { (LE) }\end{array}$ & \\
\hline \multicolumn{9}{|l|}{ I. Output Items } \\
\hline - Main Product (fodder) & Ton & 2.204 & 500.00 & 1101.88 & 318632 & 500.00 & 159315919 & $100 \%$ \\
\hline Total Output & $\mathrm{LE}$ & & & 1101.88 & & & 159315919 & \\
\hline \multicolumn{9}{|l|}{ II. Cost Items } \\
\hline \multicolumn{9}{|l|}{ Variable costs: } \\
\hline 1. maize residuals & Ton & 2.15 & 95.33 & 204.96 & 310860 & 95.33 & 29634315 & $43 \%$ \\
\hline 2. Plastic cover & $\mathrm{m} 3$ & 12.90 & 4.00 & 51.60 & 1865162 & 4.00 & 7460648 & $11 \%$ \\
\hline 3. Chemicals: & & & & 0.00 & & & 0 & \\
\hline - Urea & $\mathrm{Kg}$ & 10.75 & 2.00 & 21.50 & 1554302 & 2.00 & 3108603 & $5 \%$ \\
\hline Molas & $\mathrm{Kg}$ & 53.75 & 1.25 & 67.19 & 7771508 & 1.25 & 9714385 & $14 \%$ \\
\hline 4. Machinery & $\mathrm{HR}$ & 1.72 & 50.00 & 86.00 & 248688 & 50.00 & 12434413 & $18 \%$ \\
\hline 5. Labor & manday & 0.43 & 50.00 & 21.50 & 62172 & 50.00 & 3108603 & $5 \%$ \\
\hline 6. water & $\mathrm{m} 3$ & 0.11 & 0.50 & 0.05 & 15543 & 0.50 & 7772 & $0 \%$ \\
\hline sub-total & LE & & & 452.80 & & & 65468740 & $95 \%$ \\
\hline \multicolumn{9}{|l|}{ Fixed costs: } \\
\hline sub-total & $\mathrm{LE}$ & & & 22.93 & & & 3315438 & $5 \%$ \\
\hline Total Cost & $\mathrm{LE}$ & & & 475.73 & & & 68784178 & $100 \%$ \\
\hline \multicolumn{9}{|l|}{ III. Profit Account: } \\
\hline - Net Profit/fed. or gov. & LE/fed. & & & 626 & & & 90531741 & \\
\hline $\begin{array}{l}\text { - Net Profit/ton of } \\
\text { residues }\end{array}$ & $\mathrm{LE} /$ ton & & & 291 & & & 291 & \\
\hline $\begin{array}{l}\text { - Net Profit/ton of } \\
\text { fodder }\end{array}$ & $\mathrm{LE} /$ ton & & & 284 & & & 284 & \\
\hline - Revenue/ton & LE/ton & & & 500 & & & 500 & \\
\hline - Total cost/ton & $\mathrm{LE} /$ ton & & & 216 & & & 216 & \\
\hline - Farmer incentive & $\%$ & & & $57 \%$ & & & $57 \%$ & \\
\hline - Farmer margin & LE/ton & & & 284 & & & 284 & \\
\hline
\end{tabular}

source : Computed and applied from the Central Department of Agricultural Economics, Ministry of Agriculture. 


\section{Economic Evaluation of Feddan Recycling on governorate level}

The average total returns will be gained as results of the recycling the maize , wheat, rice and faba bean residues into nontraditional fodders during the period 2006 2011 are estimated at LE 159.3 million, LE 1877.7 million, LE 239.7 million and LE 56. 2 million, respectively, with a total of LE 2333.9 million at the governorate level. As well as the average total costs will be charged as results of the recycling the maize , wheat, rice and faba bean residues into nontraditional fodders during the period 2006 2011 are estimated at LE 68.8 million, LE 613.9 million, LE 130.1 million and LE 13.9 million, respectively, with a total of LE 826.8 million at the governorate level. Consequently, The average net profit will be gained as results of the recycling the maize , wheat, rice and faba bean residues into nontraditional fodders during the period 2006 2011 are estimated at LE 90.5 million, LE 1263.9 million, LE 109.5 million and LE 42.2 million, respectively, with a total of LE1056.2 million at the governorate level.

\section{4- Expected Economic evaluation of silage recycling.}

The farming residues budgets for the silage recycling of the sugar beet crop are estimated. The main previous economic efficient indicators are estimated.

\section{5- Sugar beet}

The inputs and outputs data for the sugar beet silage budget per feddan and per governorate are presented in table (6). The main finds shown in the table can be summarized as follows: (i) the average yields of the sugar beet residues are estimated at 4.36 ton per feddan and 116.8 thousand ton per governorate, respectively. The price of sugar beet silage is estimated at $350 \mathrm{LE} /$ ton. Therefore the total returns of sugar beet silage per feddan and per governorate are estimated at 1564 L.E/feddan and 41.9 million $\mathrm{LE} /$ governorate, respectively. (ii) The total costs of sugar beet silage per feddan and per governorate are estimated at 1034 L.E/feddan and 27.7 million LE / governorate, respectively. The costs of sugar beet residues, plastic cover, machinery, labor and water is estimated at $64 \%, 10 \%, 17 \%, 4 \%$ and $0.0 \%$, respectively of the total costs. the depreciation as a fixed cost is estimated at $4 \%$ of the total costs. (iii) the net profits per feddan and per governorate are estimated at $530 \mathrm{LE} /$ feddan and 14.2 million L.E/governorate, respectively. (iv) the net profits per ton of raw residues and per ton of fodder are estimated at L.E 122 and LE 119, respectively. (v) the farmer margin and incentive per ton of fodder are estimated at LE 119 and 34\%, respectively. (vi) the total costs per ton of fodder is estimated at $231 \mathrm{LE} / \mathrm{ton}$.

\section{5- Expected Economic evaluation of compost recycling.}

The farming residues budgets for the compost recycling of the main crops are estimated. The main previous economic efficient indicators are estimated.

\section{6- Maize}

The inputs and outputs data for the maize compost budget per feddan and per governorate are presented in table (7). The main finds shown in the table can be summarized as follows: (i) the average yields of the maize residues are estimated at 2.15 ton per feddan and 311 thousand ton per governorate, respectively. The price of maize compost is estimated at $300 \mathrm{LE} /$ ton. Therefore the total returns of maize compost per feddan and per governorate are estimated at 1129 L.E/feddan and 163.2 
Table (6): the sugar beet silage budget for feddan and for governorate, 2006-2011

\begin{tabular}{|c|c|c|c|c|c|c|c|c|}
\hline Item & Unit & Quantity & $\begin{array}{c}\text { Price } \\
\text { (LE/unit) }\end{array}$ & $\begin{array}{l}\text { Value } \\
\text { (LE) }\end{array}$ & Quantity & $\begin{array}{c}\text { Price } \\
\text { (LE/unit) }\end{array}$ & $\begin{array}{l}\text { Value } \\
\text { (LE) }\end{array}$ & $\%$ \\
\hline \multicolumn{9}{|l|}{ I. Output Items } \\
\hline - Main Product (silage) & Ton & 4.469 & 350.00 & 1564.15 & 119744 & 350.00 & 41910304 & $100 \%$ \\
\hline Total Output & $\mathrm{LE}$ & & & 1564.15 & & & 41910304 & \\
\hline \multirow{2}{*}{\multicolumn{9}{|c|}{$\begin{array}{l}\text { II. Cost Items } \\
\text { Variable costs: }\end{array}$}} \\
\hline & & & & & & & & \\
\hline 1. sugar cane leaves & Ton & 4.36 & 152.50 & 664.90 & 116823 & 152.50 & 17815530 & $64 \%$ \\
\hline 2. Plastic cover & $\mathrm{m} 3$ & 26.16 & 4.00 & 104.64 & 700939 & 4.00 & 2803756 & $10 \%$ \\
\hline 3. Chemicals: & & & & 0.00 & & & 0 & $0 \%$ \\
\hline - Urea & $\mathrm{Kg}$ & 21.80 & & 0.00 & 584116 & & 0 & $0 \%$ \\
\hline Molas & $\mathrm{Kg}$ & 109.00 & & 0.00 & 2920579 & 0.00 & 0 & $0 \%$ \\
\hline 4. Machinery & HR & 3.49 & 50.00 & 174.40 & 93459 & 50.00 & 4672926 & $17 \%$ \\
\hline 5. Labor & manday & 0.87 & 50.00 & 43.60 & 23365 & 50.00 & 1168231 & $4 \%$ \\
\hline 6. water & $\mathrm{m} 3$ & 0.22 & & 0.00 & 5841 & & 0 & $0 \%$ \\
\hline sub-total & LE & & & 987.54 & & & 26460443 & $96 \%$ \\
\hline Fixed costs: & & & & & & & & $0 \%$ \\
\hline Depreciation & LE & 218000 & $14 \%$ & 46.50 & 218000 & $14 \%$ & 1245961.2 & $4 \%$ \\
\hline sub-total & LE & & & 46.50 & & & 1245961 & $4 \%$ \\
\hline Total Cost & $\overline{L E}$ & & & 1034.04 & & & 27706404 & $100 \%$ \\
\hline \multicolumn{9}{|l|}{ III. Profit Account: } \\
\hline - Net Profit/fed. or gov. & LE/fed. & & & 530 & & & 14203900 & \\
\hline $\begin{array}{l}\text { - Net Profit/ton of } \\
\text { residues }\end{array}$ & LE/ton & & & 122 & & & 122 & \\
\hline - Net Profit/ton of silage & LE/ton & & & 119 & & & 119 & \\
\hline - Revenue/ton & LE/ton & & & 350 & & & 350 & \\
\hline - Total cost/ton & LE/ton & & & 231 & & & 231 & \\
\hline - Farmer incentive & $\%$ & & & $34 \%$ & & & $34 \%$ & \\
\hline - Farmer margin & LE/ton & & & 119 & & & 119 & \\
\hline
\end{tabular}

source : Computed and applied from the Central Department of Agricultural Economics, Ministry of Agriculture. 
Table (7): the maize compost budget for feddan and for governorate, 2006-2011

\begin{tabular}{|c|c|c|c|c|c|c|c|c|}
\hline \multirow[b]{2}{*}{ Item } & \multirow[b]{2}{*}{ Unit } & \multicolumn{3}{|c|}{ per feddan } & \multicolumn{3}{|c|}{ per governorate } & \multirow[b]{2}{*}{$\%$} \\
\hline & & $\begin{array}{l}\text { Quantity } \\
\text { (ton/fed) }\end{array}$ & $\begin{array}{c}\text { Price } \\
\text { (LE/unit) }\end{array}$ & $\begin{array}{l}\text { Value } \\
\text { (LE) }\end{array}$ & $\underset{\text { (ton) }}{\text { Quantity }}$ & $\begin{array}{c}\text { Price } \\
\text { (LE/unit) }\end{array}$ & $\begin{array}{l}\text { Value } \\
\text { (LE) }\end{array}$ & \\
\hline \multicolumn{9}{|l|}{ I. Output Items } \\
\hline $\begin{array}{l}\text { - Main Product } \\
\text { (compost) }\end{array}$ & ton & 3.76 & 300.00 & 1128.75 & 544006 & 300.00 & 163201673 & $100 \%$ \\
\hline Total Output & $\mathrm{LE}$ & & & 1128.75 & & & 163201673 & \\
\hline \multicolumn{9}{|l|}{ II. Cost Items } \\
\hline \multicolumn{9}{|l|}{ V ariable costs: } \\
\hline 2. Manure & $\mathrm{m} 3$ & 6.45 & 25.00 & 161.25 & 932581 & 25.00 & 23314525 & $27 \%$ \\
\hline 3. Chemicals: & & & & 0.00 & & & & $0 \%$ \\
\hline - Urea & $\mathrm{kg}$ & 10.75 & 2.00 & 21.50 & 1554302 & 2.00 & 3108603 & $4 \%$ \\
\hline - Calsuim Phosphate & $\mathrm{kg}$ & 10.75 & 1.50 & 16.13 & 1554302 & 1.50 & 2331452 & $3 \%$ \\
\hline 4. Machinery & $\mathrm{HR}$ & 1.08 & 80.00 & 86.00 & 155430 & 80.00 & 12434413 & $14 \%$ \\
\hline 5. Labor & manday & 1.72 & 50.00 & 86.00 & 248688 & 50.00 & 12434413 & $14 \%$ \\
\hline 6. water & $\mathrm{m} 3$ & 7.74 & 0.50 & 3.87 & 1119097 & 0.50 & 559549 & $1 \%$ \\
\hline sub-total & LE & & & 579.70 & & & 83817271 & $96 \%$ \\
\hline sub-total & LE & & & 22.93 & & & 3249129 & $4 \%$ \\
\hline Total Cost & $\mathrm{LE}$ & & & 602.64 & & & 87066400 & $100 \%$ \\
\hline \multicolumn{9}{|l|}{ III. Profit Account: } \\
\hline - Net Profit/fed. or gov. & LE/fed. & & & 526 & & & 76135273 & \\
\hline $\begin{array}{l}\text { - Net Profit/ton of } \\
\text { residues }\end{array}$ & LE/ton & & & 245 & & & 245 & \\
\hline - Net Profit/ton of fodder & LE/ton & & & 140 & & & 140 & \\
\hline - Revenue/ton & LE/ton & & & 300 & & & 300 & \\
\hline - Total cost/ton & LE/ton & & & 160 & & & 160 & \\
\hline - Farmer incentive & $\%$ & & & $47 \%$ & & & $47 \%$ & \\
\hline - Farmer margin & LE/ton & & & 140 & & & 140 & \\
\hline
\end{tabular}
source : Computed and applied from the Central Department of Agricultural Economics, Ministry of Agriculture. 


\section{¿ 9 Economic Evaluation of Farming Residues Recycling in Sharkia Governorate}

million LE/ governorate, respectively. (ii) The total costs of maize compost per feddan and per governorate are estimated at $603 \mathrm{~L}$.E/feddan and 87 million LE / governorate, respectively. The costs of maize residues, manure, urea, calcium phosphate, machinery, labor and water is estimated at $34 \%, 27 \%, 4 \%, 3 \%, 14 \%, 14 \%$ and $1 \%$, respectively of the total costs. the depreciation as a fixed cost is estimated at $4 \%$ of the total costs. (iii) the net profits per feddan and per governorate are estimated at $526 \mathrm{LE} /$ feddan and 76.1 million L.E/governorate, respectively. (iv) the net profits per ton of raw residues and per ton of maize compost are estimated at L.E 245 and LE 140, respectively. (v) the farmer margin and incentive per ton of maize compost are estimated at LE 140 and 47\%, respectively. (vi) the total costs per ton of maize compost is estimated at $160 \mathrm{LE} / \mathrm{ton}$.

\section{7- Cotton}

The inputs and outputs data for the cotton compost budget per feddan and per governorate are presented in table (8). The main finding shown in the table can be summarized as follows: (i) the average yields of the cotton residues are estimated at 1.69 ton per feddan and 72.5 thousand ton per governorate, respectively. The price of cotton compost is estimated at $300 \mathrm{LE} / \mathrm{ton}$. Therefore the total returns of cotton compost per feddan and per governorate are estimated at $887 \mathrm{~L}$.E/feddan and 38.1 million LE/ governorate, respectively. (ii) The total costs of cotton compost per feddan and per governorate are estimated at 458 L.E/feddan and 19.7 million LE / governorate, respectively. The costs of cotton residues, manure, urea, calcium phosphate, machinery, labor and water is estimated at $32 \%, 28 \%, 4 \%, 3 \%, 15 \%, 15 \%$ and $1 \%$, respectively of the total costs. the depreciation as a fixed cost is estimated at $4 \%$ of the total costs. (iii) the net profits per feddan and per governorate are estimated at $429 \mathrm{LE} /$ feddan and 18.5 million L.E/governorate, respectively. (iv) the net profits per ton of raw residues and per ton of cotton compost are estimated at L.E 354 and LE 145, respectively. (v) the farmer margin and incentive per ton of cotton compost are estimated at LE 145 and 48\%, respectively. (vi) the total costs per ton of cotton compost is estimated at $155 \mathrm{LE} / \mathrm{ton}$.

\section{8- Rice}

The inputs and outputs data for the rice compost budget per feddan and per governorate are presented in table (9). The main finds shown in the table can be summarized as follows: (i) the average yields of the rice residues are estimated at 2.14 ton per feddan and 584.5 thousand ton per governorate, respectively. The price of rice compost is estimated at $300 \mathrm{LE} /$ ton. Therefore the total returns of rice compost per feddan and per governorate are estimated at $1123.5 \mathrm{~L} . \mathrm{E} /$ feddan and 306.9 million LE/ governorate, respectively. (ii) The total costs of rice compost per feddan and per governorate are estimated at 603 L.E/feddan and 164.5 million LE / governorate, respectively. The costs of rice residues, manure, urea, calcium phosphate, machinery, labor and water is estimated at $34 \%, 27 \%, 4 \%, 3 \%, 14 \%, 14 \%$ and $1 \%$, respectively of the total costs. the depreciation as a fixed cost is estimated at $4 \%$ of the total costs. (iii) the net profits per feddan and per governorate are estimated at $521 \mathrm{LE} /$ feddan and 142.4 million L.E/governorate, respectively. (iv) the net profits per ton of raw residues and per ton of rice compost are estimated at L.E 243 and LE 139, respectively. (v) the farmer margin and incentive per ton of rice compost are estimated at LE 139 and 46\%, respectively. (vi) the total costs per ton of rice compost is estimated at $161 \mathrm{LE} /$ ton. 
Table (8): the cotton compost budget for feddan and for governorate, 2006-2011

\begin{tabular}{|c|c|c|c|c|c|c|c|c|}
\hline \multirow[b]{2}{*}{ Item } & \multirow[b]{2}{*}{ Unit } & \multicolumn{3}{|c|}{ per feddan } & \multicolumn{3}{|c|}{ per governorate } & \multirow[b]{2}{*}{$\%$} \\
\hline & & $\begin{array}{l}\text { Quantity } \\
\text { (ton/fed) }\end{array}$ & $\begin{array}{c}\text { Price } \\
\text { (LE/unit) }\end{array}$ & $\begin{array}{l}\text { Value } \\
\text { (LE) }\end{array}$ & $\underset{\text { (ton) }}{\text { Quantity }}$ & $\begin{array}{c}\text { Price } \\
\text { (LE/unit) }\end{array}$ & $\begin{array}{l}\text { Value } \\
\text { (LE) }\end{array}$ & \\
\hline \multicolumn{9}{|l|}{ I. Output Items } \\
\hline - Main Product (compost) & ton & 2.96 & 300.00 & 887.25 & 127042 & 300.00 & 38112534 & $100 \%$ \\
\hline Total Output & LE & & & 887.25 & & & 38112534 & \\
\hline \multicolumn{9}{|l|}{ II. Cost Items } \\
\hline \multicolumn{9}{|l|}{ Variable costs: } \\
\hline 1. cotton residues & ton & 1.69 & 86.00 & 145.34 & 72595 & 86.00 & 6243196 & $32 \%$ \\
\hline 2. Manure & $\mathrm{m} 3$ & 5.07 & 25.00 & 126.75 & 217786 & 25.00 & 5444648 & $28 \%$ \\
\hline 3. Chemicals: & & & & 0.00 & & & & $0 \%$ \\
\hline - Urea & $\mathrm{kg}$ & 8.45 & 2.00 & 16.90 & 362977 & 2.00 & 725953 & $4 \%$ \\
\hline - Calsuim Phosphate & $\mathrm{kg}$ & 8.45 & 1.50 & 12.68 & 362977 & 1.50 & 544465 & $3 \%$ \\
\hline 4. Machinery & $\mathrm{HR}$ & 0.85 & 80.00 & 67.60 & 36298 & 80.00 & 2903812 & $15 \%$ \\
\hline 5. Labor & manday & 1.35 & 50.00 & 67.60 & 58076 & 50.00 & 2903812 & $15 \%$ \\
\hline 6. water & $\mathrm{m} 3$ & 6.08 & 0.50 & 3.04 & 261343 & 0.50 & 130672 & $1 \%$ \\
\hline sub-total & $\mathrm{LE}$ & & & 439.91 & & & 18896557 & $96 \%$ \\
\hline Fixed costs: & & & & & & & & $0 \%$ \\
\hline Depreciation & LE & 218000 & $14 \%$ & 18.02 & 218000 & $14 \%$ & 758770 & $4 \%$ \\
\hline sub-total & LE & & & 18.02 & & & 758770 & $4 \%$ \\
\hline Total Cost & LE & & & 457.93 & & & 19655327 & $100 \%$ \\
\hline \multicolumn{9}{|l|}{ III. Profit Account: } \\
\hline - Net Profit/fed. or gov. & LE/fed. & & & 429 & & & 18457206 & \\
\hline - Net Profit/ton of residues & LE/ton & & & 254 & & & 254 & \\
\hline - Net Profit/ton of fodder & LE/ton & & & 145 & & & 145 & \\
\hline - Revenue/ton & LE/ton & & & 300 & & & 300 & \\
\hline - Total cost/ton & LE/ton & & & 155 & & & 155 & \\
\hline - Farmer incentive & $\%$ & & & $48 \%$ & & & $48 \%$ & \\
\hline - Farmer margin & LE/ton & & & 145 & & & 145 & \\
\hline
\end{tabular}

source : Computed and applied from the Central Department of Agricultural Economics, Ministry of Agriculture. 
Table (9): the rice compost budget for feddan and for governorate, 2006-2011

\begin{tabular}{|c|c|c|c|c|c|c|c|c|}
\hline \multirow[b]{2}{*}{ Item } & \multirow[b]{2}{*}{ Unit } & \multicolumn{3}{|c|}{ per feddan } & \multicolumn{3}{|c|}{ per governorate } & \multirow[b]{2}{*}{$\%$} \\
\hline & & $\begin{array}{l}\text { Quantity } \\
\text { (ton/fed) }\end{array}$ & $\begin{array}{c}\text { Price } \\
\text { (LE/unit) }\end{array}$ & $\begin{array}{l}\text { Value } \\
\text { (LE) }\end{array}$ & $\underset{\text { (ton) }}{\text { Quantity }}$ & $\begin{array}{l}\text { Price } \\
\text { (LE/unit) }\end{array}$ & $\begin{array}{l}\text { Value } \\
\text { (LE) }\end{array}$ & \\
\hline \multicolumn{9}{|l|}{ I. Output Items } \\
\hline Total Output & $\mathrm{LE}$ & & & 1123.50 & & & 306874812 & \\
\hline \multicolumn{9}{|l|}{ II. Cost Items } \\
\hline \multicolumn{9}{|l|}{ Variable costs: } \\
\hline 1. rice residues & Ton & 2.14 & 96.70 & 206.94 & 584523 & 96.70 & 56523418 & $34 \%$ \\
\hline 3. Chemicals: & & & & 0.00 & & & & $0 \%$ \\
\hline - Urea & $\mathrm{Kg}$ & 10.70 & 2.00 & 21.40 & 2922617 & 2.00 & 5845235 & $4 \%$ \\
\hline - Calcium Phosphate & $\mathrm{Kg}$ & 10.70 & 1.50 & 16.05 & 2922617 & 1.50 & 4383926 & $3 \%$ \\
\hline 4. Machinery & HR & 1.07 & 80.00 & 85.60 & 292262 & 80.00 & 23380938 & $14 \%$ \\
\hline 5. Labor & manday & 1.71 & 50.00 & 85.60 & 467619 & 50.00 & 23380938 & $14 \%$ \\
\hline 6. water & $\mathrm{m} 3$ & 7.70 & 0.50 & 3.85 & 2104284 & 0.50 & 1052142 & $1 \%$ \\
\hline sub-total & LE & & & 579.94 & & & 158405855 & $96 \%$ \\
\hline Fixed costs: & & & & & & & & $0 \%$ \\
\hline Total Cost & $\mathrm{LE}$ & & & 602.76 & & & 164515327 & $100 \%$ \\
\hline \multicolumn{9}{|l|}{ III. Profit Account: } \\
\hline - Net Profit/fed. or gov. & LE/fed. & & & 521 & & & 142359486 & \\
\hline - Net Profit/ton of residues & $\mathrm{LE} /$ ton & & & 243 & & & 244 & \\
\hline - Net Profit/ton of fodder & LE/ton & & & 139 & & & 139 & \\
\hline - Revenue/ton & LE/ton & & & 300 & & & 300 & \\
\hline - Total cost/ton & LE/ton & & & 161 & & & 161 & \\
\hline - Farmer incentive & $\%$ & & & $46 \%$ & & & $46 \%$ & \\
\hline - Farmer margin & LE/ton & & & 139 & & & 139 & \\
\hline
\end{tabular}

source : Computed and applied from the Central Department of Agricultural Economics, Ministry of Agriculture 


\section{Economic Evaluation of Feddan Recycling on governorate level}

The average total returns will be gained as results of the recycling the maize , cotton and rice residues into compost during the period 2006 - 2011 are estimated at LE 163.2 million, LE 38.1 million and LE 306.9 million, respectively, with a total of LE 508.2 million at the governorate level. In addition the average total costs will be charged as results of the recycling the maize, cotton and rice residues into compost during the period 2006 - 2011 are estimated at LE 87.1 million, LE 19.7 million and LE 164.5 million, respectively, with a total of LE 271.2 million at the governorate level. Consequently, The average net profit will be gained as results of the recycling the maize, cotton and rice residues into compost during the period 2006 - 2011 are estimated at LE 76.1 million, LE 18.5 million and LE 142.4 million, respectively, with a total of LE 236.9 million at the governorate level.

6- The economic valuation of soil nutrients compounds.

The chemical composition of agricultural residues on a dry matter basis is shown in table (10). These amounts are averages used as a guide only, and may have an actual significant difference from these numbers according to the method of collection and treatment of waste and how to save it.

Table (10): The chemical composition of agricultural residues on a dry matter basis

\begin{tabular}{|c|c|c|c|c|c|}
\hline Residues compost & $\begin{array}{c}\text { Organic } \\
\text { matter }\end{array}$ & Nitrogen & Phosphorus & Potassium & TDN \\
\hline Maize & $80 \%$ & $0.55 \%$ & $0.31 \%$ & $1.11 \%$ & $63.37 \%$ \\
\hline Cotton & $75 \%$ & $0.88 \%$ & $0.15 \%$ & $1.45 \%$ & $42.06 \%$ \\
\hline Sugar beet & $70 \%$ & $1.50 \%$ & $0.30 \%$ & $0.15 \%$ & $3.51 \%$ \\
\hline Faba bean & $80 \%$ & $1.00 \%$ & $0.32 \%$ & $1.34 \%$ & $34.31 \%$ \\
\hline Rice & $75 \%$ & $0.58 \%$ & $0.10 \%$ & $1.38 \%$ & $61.39 \%$ \\
\hline Wheat & $79 \%$ & $0.54 \%$ & $0.11 \%$ & $1.06 \%$ & $64.26 \%$ \\
\hline
\end{tabular}

Source: Ministry of Agriculture, Economic Affairs Sector, Central Department of Agricultural Economics, Bulletin of Agricultural Statistics, Egypt,

The amounts of digested nutrients that can be provided by the studied farming residues to the soil when used as an organic fertilizer (residues composts) in Sharkia governorate are represented in table 11. The data in the table shows that: (i) the total amounts of organic matter, nitrogen, phosphorus, potassium and TDN (total Digestible Nutrients) are estimated at 1.82 million ton, 14.4 thousand ton, 3.46 thousand ton, 26.2 thousand ton and 1.39 million ton, respectively.

Table (11): The amount of digested nutrients that can be provided by agricultural farm residues to the soil when used as an organic fertilizer (compost) in Sharkia governorate.

\begin{tabular}{|c|c|c|c|c|c|c|}
\hline Residues compost & $\begin{array}{c}\text { Residues } \\
\text { quantity (ton) }\end{array}$ & $\begin{array}{c}\text { organic } \\
\text { matter } \\
\text { (ton) }\end{array}$ & $\begin{array}{c}\text { Nitrogen } \\
\text { (ton) }\end{array}$ & $\begin{array}{c}\text { phosphorus } \\
\text { (ton) }\end{array}$ & $\begin{array}{c}\text { potassium } \\
\text { (ton) }\end{array}$ & $\begin{array}{c}\text { TDN } \\
\text { (ton) }\end{array}$ \\
\hline Rice & 584523 & 438393 & 3390 & 585 & 8066 & 358839 \\
\hline Faba bean & 36558 & 29247 & 366 & 117 & 490 & 12543 \\
\hline Wheat & 1221313 & 964837 & 6595 & 1343 & 12946 & 784816 \\
\hline Maize & 309080 & 247264 & 1700 & 958 & 3431 & 195864 \\
\hline Cotton & 72595 & 54446 & 639 & 109 & 1053 & 30534 \\
\hline Sugar beet & 116823 & 81776 & 1752 & 350 & 175 & 4100 \\
\hline Total & 2340894 & 1815963 & 14442 & 3462 & 26161 & 1386696 \\
\hline
\end{tabular}

Source: Calculated and estimated by data in tables ( 1 and 10). 
Taken in consideration the free market prices of the studied nutrients in the residues composts which is $0.15 \mathrm{LE} / \mathrm{kg}$ of organic matter, $3.2 \mathrm{LE} / \mathrm{kg}$ of nitrogen, 1.36 $\mathrm{LE} / \mathrm{kg}$ of of phosphorus, $4.8 \mathrm{LE} / \mathrm{kg}$ of potassium and $0.6 \mathrm{LE} / \mathrm{kg}$ of TDN. The economic values of the studied nutrients by residues compost are presented in table 12. The results in the table indicate that: (i) the economic values of digested nutrients of wheat, rice, maize, cotton, sugar beet and faba bean composts in Sharkia governorate are estimated at LE 700.7 million, LE 331.4 million, LE 177.8 million, LE 33.7 million, LE 21.6 million and LE 15.5 million, respectively, with total value of LE 1.28 billion. (ii) the economic values of digested nutrients of organic matter, nitrogen, phosphorus, potassium and TDN in Sharkia governorate are estimated at LE272.3 million, LE 46.2 million, LE 4.7 million, LE 125.5 million and LE 832 million, respectively, with total value of LE 1.28 billion.

Table (12): The economic values of the amount of digested nutrients in the organic fertilizer (residues composts) in Sharkia governorate.

\begin{tabular}{|c|c|c|c|c|c|c|}
\hline CROP & $\begin{array}{c}\text { organic } \\
\text { matter } \\
(\mathbf{0 0 0} \text { LE) }\end{array}$ & $\begin{array}{c}\text { Nitrogen } \\
(\mathbf{0 0 0} \text { LE) }\end{array}$ & $\begin{array}{c}\text { phosphorus } \\
(\mathbf{0 0 0} \text { LE) }\end{array}$ & $\begin{array}{c}\text { potassium } \\
(\mathbf{0 0 0} \text { LE) }\end{array}$ & $\begin{array}{c}\text { TDN (000 } \\
\text { LE) }\end{array}$ & $\begin{array}{c}\text { Total (000 } \\
\mathbf{L E )}\end{array}$ \\
\hline Rice & 65759 & 10849 & 795 & 38719 & 215303 & 331425 \\
\hline Faba bean & 4387 & 1170 & 159 & 2351 & 7526 & 15593 \\
\hline Wheat & 144726 & 21104 & 1827 & 62140 & 470889 & 700687 \\
\hline Maize & 37090 & 5440 & 1303 & 16468 & 117519 & 177819 \\
\hline Cotton & 8167 & 2044 & 148 & 5053 & 18320 & 33732 \\
\hline Sugar beet & 12266 & 5608 & 477 & 841 & 2460 & 21652 \\
\hline Total & 272395 & 46215 & 4709 & 125572 & 832018 & 1280908 \\
\hline
\end{tabular}

Source: Calculated and estimated by data in table (11).

\section{7- The economic valuation of labour opportunities creation.}

A lot of job opportunities in rural areas in the governorate will be created during the recycling the maize, wheat, rice and faba bean residues into nontraditional fodders. Processing the nontraditional fodder from the farming residues needs 0.2 manday per ton of residues. Therefore, the huge quantities of maize, wheat, rice and faba bean residues at the governorate level (tables 2-5) will require enormous job opportunities. The quantities of labor needed for processing the maize, wheat, rice and faba bean nontraditional fodders at the governorate level are estimated at 62172 manday, 244263 manday, 116905 manday and 7312 manday, respectively, with a total of 430651 manday. Assuming the average wage rate of manday is LE 50 per day. Consequently, the value of labour used in the recycling the nontraditional fodder is LE 21.5 million. So the labour force in the rural areas in the governorate will gain about of LE 21.5 million as results of processing the farming residues of maize, wheat, rice and faba bean into nontraditional fodders.

Similarly many of job opportunities in rural areas in the governorate will be created during the recycling the maize, cotton and rice residues into composts. Processing the compost from the farming residues needs 0.8 manday per ton of residues. Therefore, the huge quantities of maize, cotton and rice residues at the governorate level (tables 7-9) will require enormous job opportunities. The quantities of labor needed for processing the maize, cotton and rice composts at the governorate level are estimated at 238688 manday, 58067 manday and 467619 manday, respectively, with a total of 774383 manday. Assuming the average wage rate of manday is LE 50 per day. Consequently, the value of labour used in the recycling the 
compost is LE 38.7 million. So the labour force in the rural areas in the governorate will gain about of LE 38.7 million as results of processing the farming residues of maize, cotton and rice into composts.

\section{5- Recommendations:}

1- Promoting cooperation between research bodies and industrial enterprises in order to facilitate the identification of problems and sources of bottlenecks and constraints that limit the optimum utilization of farming residues and thus lead to the scientific and practical solutions to these problems.

2- Provision of machinery and equipment necessary for the establishment of small projects in the field of recycling of farming residues.

3-Work to raise awareness of environmental and health among the citizens through seminars and conferences to discuss important economic, social, environmental and health resulting from the recycling of farming residues.

4-Encourage the use of organic fertilizers (farming residues composts) as alternatives to economic and safe for the production of healthy food and safe compared to chemical fertilizers are detrimental to health and environmentally.

6- References:

A grower's guide., 1999.Compost production and unitization. California Department of food and Agriculture, University of California. USA.pp:1-176.

Gray, K.R., and K. Sherman, 1970. Public Cleansing. 60 (7) : 343 - 354.

Abd El-Hady, A. H. 1993. Potassium and its effects on crop productivity in Egyptian soils. Bull. (in Arabic). Soils and Water Res. Inst., Agric. Res. Centre, Giza. Egypt.

Abdulai, A., and P.P. Regmi. 2000. IEstimating labor supply of farm households under nonseparability:Empirical evidence from Nepal." Agricultural Economics 22:309\{320.

Abou El- Azayem M.G.M., and Abd El-Ghani S. S. 2010. Economic Return of Recycling the Agricultural Wastes in Egypt and Spain. Journal of American Science, 6(12).

Abou Hussein S.D., and Sawan Omaima M. 2010. The Utilization of Agricultural Waste as One of the Environmental Issues in Egypt. Journal of Applied Sciences Research, 6(8): 1116-1124.

Barnard, G. and L. Kristoferson, 1985. Agricultural residues as fuel in the third world. Earthscan, Technical Report No. 4, IIED, London.

Bendary, M.M. \& M.A. Younis 1997. Evaluation of maize stalks for feeding dairy cows. Egypt. J. Appl. Sci., 12 (8) 1997.

Berazneva, J. 2013. Economic value of crop residues in African smallholder agriculture. Selected Paper prepared for presentation at the Agricultural and Applied Economics, Washington, DC.

El-Shimi, S. A., 2000."biogas", Agricultural Research Center, Department of Culture agricultural, technical publication No. 7, Egypt.

European Commission, 2005 "Europeans and the Common Agricultural Policy", Special Euro barometer, 221/Wave 622 - TNS Opinion and Social.

Garrett, W.N., 1978. The value of rice straw compared to alfalfa hay for feedlot diets. Proc.Western Section Amer. Soc. Anim. Sci.29:375-378. 
Salvador P, Fernando J. A., Javier C. 2007"Increased producer and consumer preoccupation with environment. Economic internalization of greenhouse vegetal waste impact in Almerian horticulture, Spain".

\section{ABSTRACT}

Agricultural wastes in Egypt amount range from 30-35 million tons a year of which only 7 million tons as animal feed and 4 million as organic manure are being utilized. These crop residues results after harvesting in the farm of leaves, stem and shelves which are characterized as Coarse plant byproducts and big size, chemically low in protein and fat contents, also it is high in lignin and cellulous contents.

The main problems facing rural Production that agriculture wastes becomes very obvious and aggregated after the harvest of crops that is because farmer is in a rush to re-cultivate his land therefore getting rid of the wastes has his highest priorities, usually by burning. This, burning not only is considered as an economic loss but also has harmful effects on the environment, these harmful effects are emission of poisons gases to the air and reducing the microbial activities in the soil. In addition, storing these wastes in the field after compacting underground may make it suitable environment for reproduction and growth of pests and pathogens that will attack new crops.

So it can be concluded that recycling agriculture wastes is important for environment as well as economical saving, This recycling will not only increase agricultural production but also will improve its quality, So the main objective of this study is analyzing and estimating the expected economic evaluation of crop residues recycling in Sharkia governorate. To acheive the previous objective we estimated the following:

The by-products values generated from the main cultivated crops.

The technical and economic efficient indicators of the most important farming residues recycling.

The economic evaluation of soil nutrients compounds (organic matter, nitrogen, phosphate, potassium and total digestible nutrients (TDN)) as result of the processing and recycling the studied farming residues .

The labour opportunities as result of the processing and recycling the studied farming residues.

A descriptive statistical analysis has been applied, in addition the complete and partial crop budgets have been used to analyze the on farm incomes. The crop residues budgets have been computed for the cultivated main crops ( sugar beet, rice, wheat, maize and cotton), and have been chosen based on the cultivation area in Sharkia governorate during the period 2006-2011.

By estimating the previous analysis some results has been reached which include the following:

Expected Economic evaluation of Nontraditional Fodder by recycling the farming residues budgets for the nontraditional fodder recycling of the main cultivated crops are estimated, at governorate level and showed that the average net profit will be gained as results of the recycling the maize, wheat, rice and faba bean 
residues into nontraditional fodders during the period 2006 - 2011, at sharkia governorate level.

Expected Economic evaluation of compost recycling are estimated, at governorate level and showed that the average net profit will be gained as results of the recycling the maize, cotton and rice residues into compost during the period 2006 - 2011 at sharkia governorate level.

The economic evaluation of soil nutrients compounds are estimated, at governorate level and showed that the amounts of digested nutrients that can be provided by the studied farming residues to the soil when used as an organic fertilizer (residues composts) in Sharkia governorate.

The economic valuation of labour opportunities creation are estimated, at governorate level and showed that many of job opportunities in rural areas in the governorate will be created during the recycling the maize, cotton and rice residues into composts.

So that from the previos results this study recommended to encourage the use of organic fertilizers (farming residues composts) as alternatives to economic and safe for the production of healthy food and safe compared to chemical fertilizers are harmful to health and environmentally, In addition,work to raise awareness of environmental and health among the citizens through seminars and conferences to discuss important economic, social, environmental and health resulting from the recycling of farming residues.

\section{التقييم الاقتصادي لتدوير المخلفات المزرعية في محافظة الشرقية}

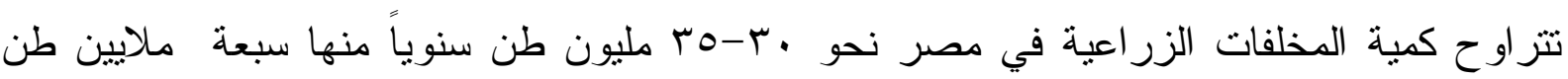

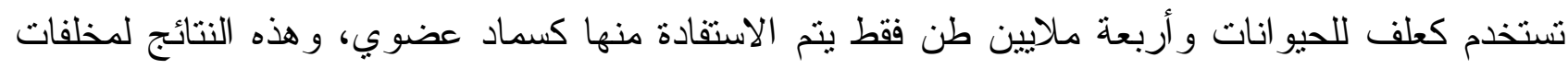

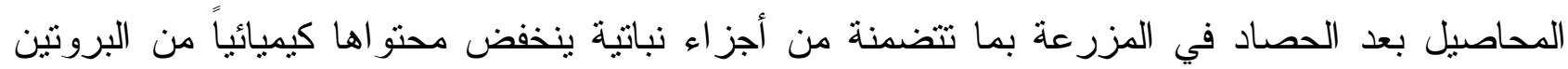

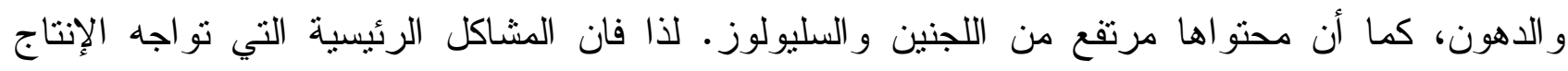

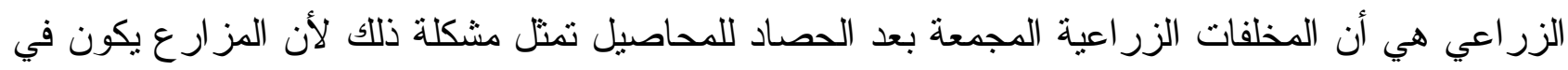

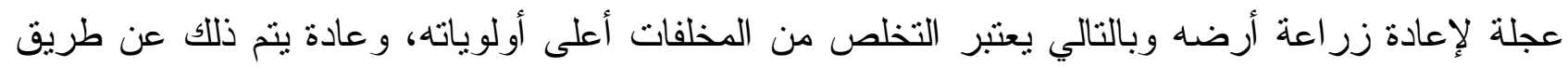

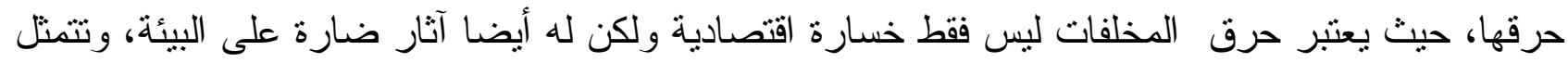

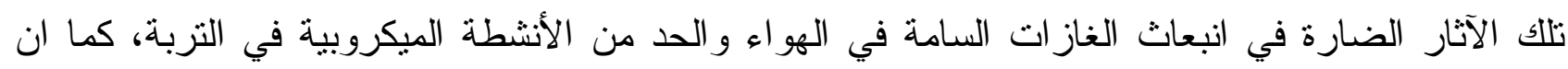

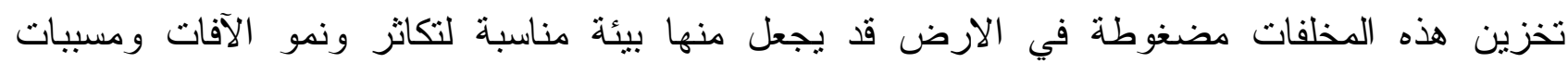
الأمر اض التي تهاجم وتضر بالمحاصيل الجديدة.

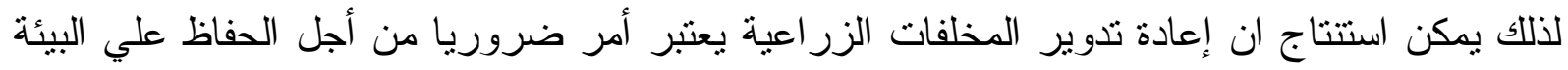

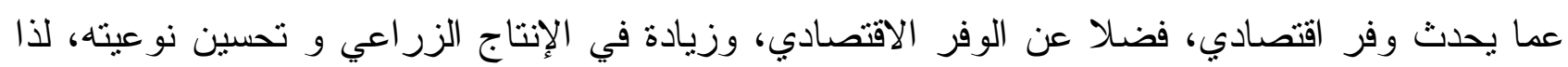

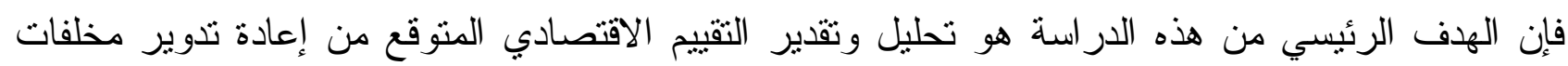

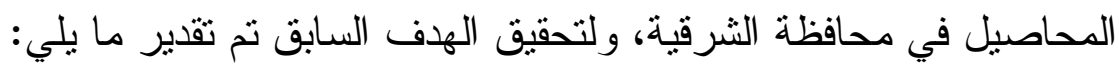
- قيم المنتجات الثانوية الناتجة من المحاصيل الرئيسية المزرو عة. 
- تقدير المؤشرات الفنبة والاقتصادية الفعالة لإعادة تدوير المخلفات الزر اعية الأكثر أهمية.

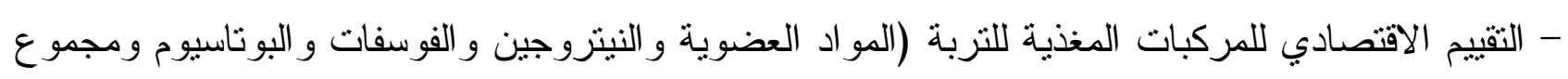

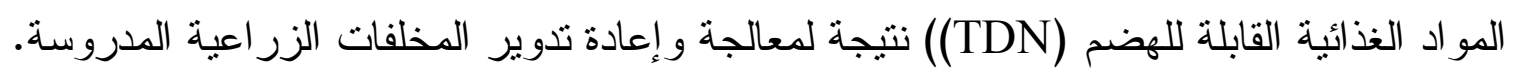

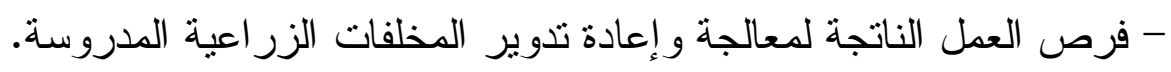

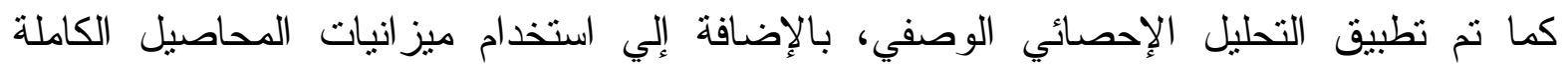

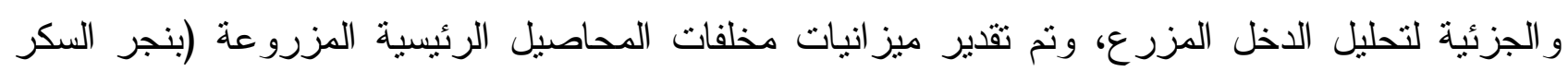

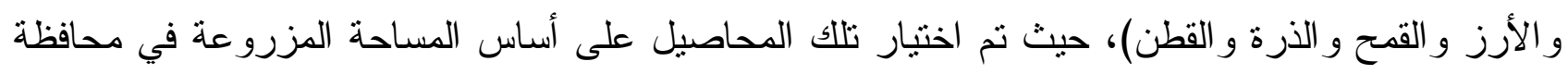

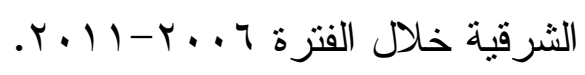

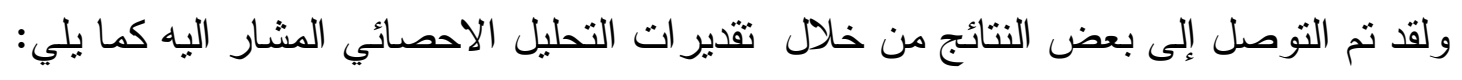

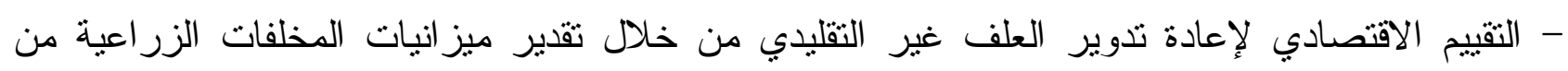

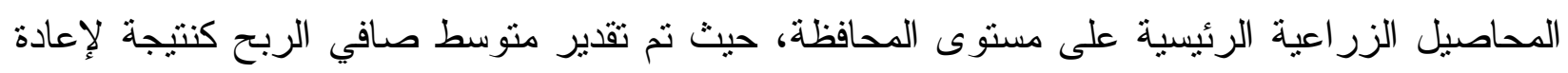

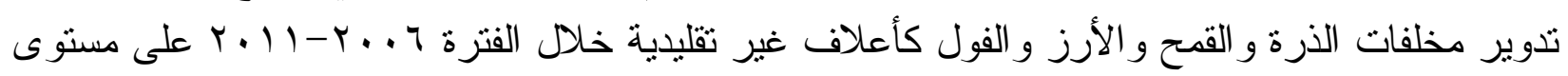
محافظة الثرقية.

- التقييم الاقتصادي لإعادة تذوير السماد، حيث تم تقدير منوسط صافي الربح لإعادة تدوير مخلفات الذرة

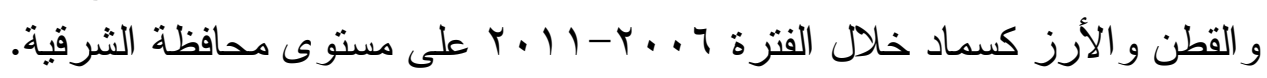

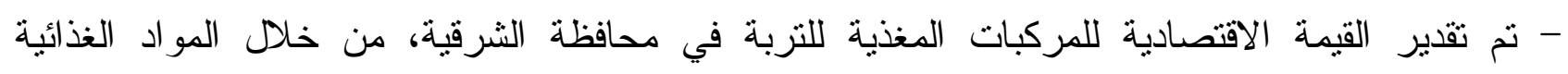

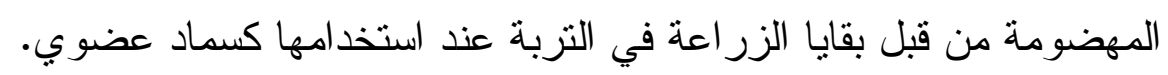

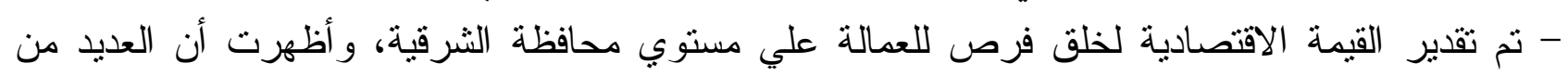

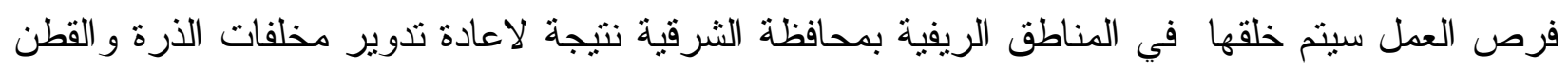
و الأرز وتحويلها إلى سماد.

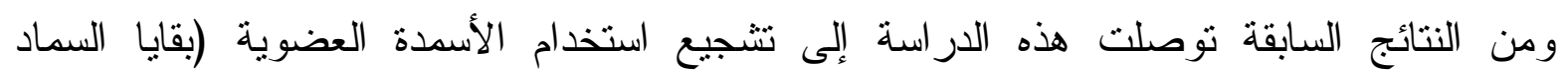

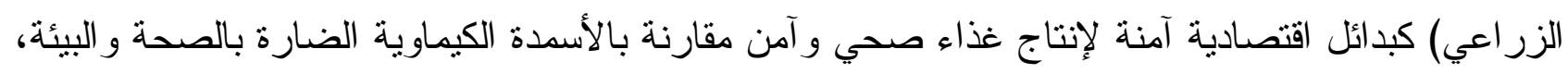

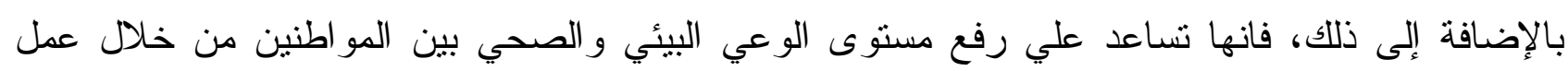

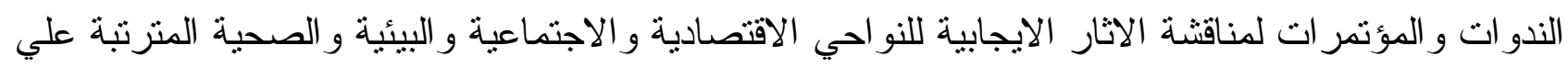
إعادة تدوير المخلفات الزر اعية. 